\title{
In vitro effect of hydroalcoholic extract of Peganum harmala on human ureteric contractions
}

\author{
Majid Shirani $^{1 \oplus}$, Zahra Lorigooini $^{2^{\circledR}}$, Arsham Pouriamofrad $^{3}{ }^{(\mathbb{D}}$, Zahra Keivani Hafshejani $^{3^{*}}$ \\ ${ }^{1}$ Department of Urology, Shahrekord University of Medical Sciences, Shahrekord, Iran \\ ${ }^{2}$ Medical Plants Research Center, Basic Health Sciences Institute, Shahrekord University of Medical Sciences, Shahrekord, Iran \\ ${ }^{3}$ Deputy of Research and Technology, Shahrekord University of Medical Sciences, Shahrekord, Iran
}

\section{A R T I C LE I N F O}

Article Type:

Original

\section{Article History:}

Received: 3 April 2019

Accepted: 20 May 2019

Published online: 15 June 2019

\section{Keywords:}

Peganum harmala

Ureter

Prazosin

Renal colic

\begin{abstract}
A B S T RA C T
Introduction: Ureteral obstruction by stones is one of the most common urological problems. Objectives: This study aimed to investigate the in vitro effects of hydroalcoholic extract of Peganum harmala L. on the contraction of the human ureter.

Materials and Methods: In this study, 28 samples of human ureter tissue were studied. Six tissue samples were examined for the evaluation of $P$. harmala extract at concentrations of 1,2 , and $4 \mathrm{mg} / \mathrm{mL}$. Moreover, five tissue samples were examined for checking $\mathrm{NaCl}$ solution since, six pieces of tissue for the examination of prazosin 10-8M solution.

Results: There was a significant difference between the second contraction of $P$. harmala group with concentration of $4 \mathrm{mg} / \mathrm{mL}$ and $\mathrm{NaCl}$ group $(P<0.001)$. Additionally, a significant difference between the prazosin and $P$. harmala groups with a concentration of $4 \mathrm{mg} / \mathrm{mL}$ $(P=0.048)$ was observed. There is a marginal difference between the secondary contractions in two groups. A significant decrease in secondary contraction (15 minutes after adding the solution) was observed between the prazosin group and the $P$. harmala group at a concentration of $1 \mathrm{mg} / \mathrm{mL}(P<0.001)$. Moreover, the secondary contraction of the prazosin group showed a significant decrease compared with the $\mathrm{NaCl}$ group $(P<0.001)$.

Conclusion: Administration of $P$. harmala extract can be useful in reducing urinary human ureteric contractions while the best effect was achieved at $4 \mathrm{mg} / \mathrm{mL}$ of $P$. harmala extract.
\end{abstract}

\section{Implication for health policy/practice/research/medical education:}

Administration of Peganum harmala extract can be useful in reducing urinary ureteric contractions as a supplementary drug.

Please cite this paper as: Shirani M, Lorigooini Z, Pouriamofrad A, Keivani Hafshejani Z. In vitro effect of hydroalcoholic extract of Peganum harmala on human ureteric contractions. J Renal Inj Prev. 2019;8(3):235-239. DOI: 10.15171/jrip.2019.44.

\section{Introduction}

Renal colic is one of the most commonly referred cases of emergency ward seen among the people aged 30 to 40 years with prevalence of 3 in 1000 every year, which is usually described as a severe pain in the flanks that is spread to the inguinal region and is associated with nausea and vomiting in $50 \%$ of people. In the United States, $40 \%$ of the people refer to the emergency ward for the first time due to the renal colic, which has been doubled over the past decade (1-3). The prevalence of this disease is in both genders and all races, although it is seen more in the African-American and Caucasian breeds. Most of the causes of renal colic are due to the presence of upper urinary tract stones and urinary tract obstruction, and about $80 \%$ of the urinary tract stones are of calcium oxalate type (2). One of the most common causes of ureteral obstruction is the movement of stones from the kidneys and their capture in the ureter.
This discomfort causes severe pain, which is characterized by sudden acute pain, nausea, vomiting, pallor, hematuria, and change in the color of the urine and, in those who have a single kidney, anuria can be mentioned as a sign of strangulation of the stone in the ureter (1-3). Although the ureteric tissue is without extensive nerve tissue, there are several receptors including cholinergic and adrenergic receptors on the ureteric tissue, while $70 \%$ of which is alpha-adrenergic. Alpha-receptors are stimulated by the epinephrine and phenylephrine increased contractions, and alpha receptor blockers, such as prazosin reduces tissue contractions (1-3).

One of the plants that have been considered in traditional medicine in Iran for a long time is Peganum harmala. The alkaloids of this plant have extensive pharmacological effects in various fields such as antispasmodics, anticancer effects $(4,5)$, antihistaminic monoamine oxidase inhibitors 
(6), agonist to receptors such as 5-TH and binding to benzodiazepine receptors (7), anti-platelet aggregation (8), immunomodulatory effect (9), and also the effect of decreasing blood pressure (10). Based on previous studies and the similarity of the receptors on the ureter and muscle tissue of the prostate, drugs that affect the reduction of ureteric contractions can be expected to have a similar effect on the contraction of the prostate tissue and to reduce the symptoms of the lower urinary system.

\section{Objectives}

The present study was aimed to determine the in vitro effect of Peganum harmala extract on human ureteric contractions.

\section{Patients and Methods}

\section{Preparation of the herbal extract}

Peganum harmala was prepared and authenticated by expert botanists. A voucher specimen was deposited in Herbarium of Medical Plants Research center, Shahrekord University of Medical Sciences. The seeds were ground by a mechanical grinder. The $70 \%$ hydroalcoholic extract was prepared using maceration method at room temperature. The extract was then filtered and evaporated using vacuum rotary evaporator.

The present study was an experimental-interventional study. The studied ureteral tissue was separated from total nephrectomy. Uterine tissues have not been involved with cancer cells, tissue infection, and abnormal dilatation of the ureters. In this experimental study, 28 samples of human ureter tissue were studied. Six tissue samples were examined for evaluation at concentration of $1 \mathrm{mg} / \mathrm{mL}, 6$ tissue samples at concentration of $2 \mathrm{mg} / \mathrm{mL}$, and 5 tissues at $4 \mathrm{mg} / \mathrm{mL}$ concentration of $P$. harmala extract. Also, 5 tissue samples were examined for checking normal saline solution and 6 pieces of tissue for checking prazosin $10^{-8} \mathrm{M}$ solution. The ureter tissue was removed by nephrectomy with any reason, placed in a UW solution at $0^{\circ} \mathrm{C}$, and immediately transferred to the lab. The ureter was separated with the size of one to $2 \mathrm{~cm}$, put in a bath of oxygenated Krebs solution at $37^{\circ} \mathrm{C}(\mathrm{pH}=4.7)$, and then placed vertically between two hooks of stainless steel. The upper hook was connected to an isometric transducer by a thread and then to the physiography device. One gram weight on the opposite side of the transducer lever hangs on the tissue to make a primitive stretch. Then, by adding potassium chloride, the tissue was contracted and, after reaching to maximum contraction to examine the mechanism of the effect of the extract, was incubated with $P$. harmala, normal saline, and prazosin extracts, and the percentage of contraction force changes on paper was recorded and calculated.

\section{Ethical issues}

The research followed the tenets of the Declaration of Helsinki. This research was approved by the Ethics Committee of Shahrekord University of Medical Sciences. (Ethics Committee reference number: IR.SKUMS. REC.1395.233). Additionally, Shahrekord University of Medical Sciences supported this research financially (Grant\#1462). This study was conducted as the M.D., thesis of Arsham Pouriamofrad at this university.

\section{Statistical analysis}

Data were analyzed by the Prism using descriptive, ANOVA, and Tukey tests. $P$ value less than 0.05 was considered statistically significant.

Results

In this study, 28 samples of human ureter tissue were studied. Six tissue samples were examined for evaluation of $P$. harmala solution at concentration of $1 \mathrm{mg} / \mathrm{mL}, 6$ tissue samples at concentration of $2 \mathrm{mg} / \mathrm{mL}$, and 5 pieces of tissue for evaluation of $P$. harmala solution at $4 \mathrm{mg} /$ $\mathrm{mL}$ concentration. Also, 5 tissue samples were examined for checking $\mathrm{NaCl}$ solution and 6 pieces of tissue for examination of prazosin solution.

As shown in Table 1, distribution of data using the Shapiro-Wilk test, as global, and in terms of the examined groups was normal $(P<0.05)$. ANOVA was used to compare contraction between the groups. There was no significant difference between the initial contraction after adding $\mathrm{KCl}(P=0.21)$, but there was a significant difference between the secondary contraction (15 minutes after the addition of $\mathrm{NaCl}$, prazosin and $P$. harmala extracts $) \quad(P<0.05)$.

As shown in Figure 1, two-way ANOVA was used to compare the contraction between the groups. Bonferroni post analysis showed that there was no significant difference between initial tension after adding $\mathrm{KCl}(\mathrm{P}=$ 0.21 ), but there was a significant difference between secondary contraction (15 minutes after adding $\mathrm{NaCl}$, prazosin and $P$. harmala $)(P<0.05)$.

A significant decrease in secondary contraction (15 minutes after adding the solution) was observed between the prazosin group and the $P$. harmala group at a concentration of $1 \mathrm{mg} / \mathrm{mL}(P<0.001)$. Besides, the secondary contraction of the prazosin group showed a significant decrease compared with that of the $\mathrm{NaCl}$ group

Table 1. Total values of initial pull (after adding $\mathrm{KCl}$ ) and secondary contraction (after adding $\mathrm{NaCl}$, prazosin and Peganum harmala extracts)

\begin{tabular}{lcc}
\hline Group & $\begin{array}{c}\text { Contraction } \\
\text { after adding } \\
\mathrm{KCL}\end{array}$ & $\begin{array}{c}\text { Contraction after adding } \\
\mathrm{NaCl} \text {, Prazosin and Peganum } \\
\text { harmala extracts }\end{array}$ \\
\hline Prazosin & $3.9 \pm 0.6$ & $1.08 \pm 0.4$ \\
$\mathrm{NaCl}$ & $4.3 \pm 0.7$ & $3.9 \pm 0.7$ \\
Peganum harmala & $4.4 \pm 0.5$ & $3.05 \pm 0.8$ \\
$P$ & 0.21 & $<0.05$ \\
\hline
\end{tabular}




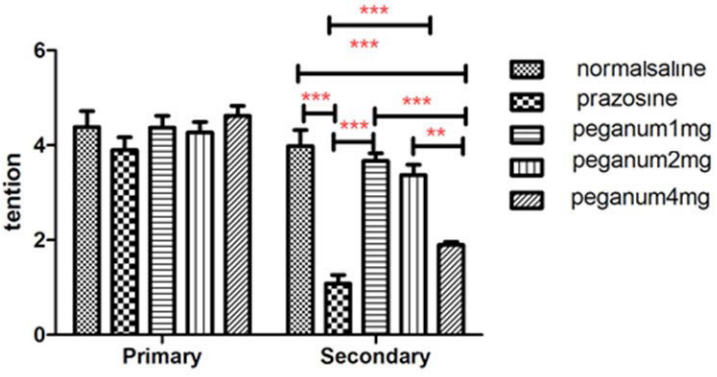

Figure 1. Comparison tension in the primary and secondary groups.

$(P<0.001)$. However, there was no significant difference in the secondary contraction reduction between the $P$. harmala group treated with concentration of $1 \mathrm{mg} / \mathrm{mL}$ and $\mathrm{NaCl}$ group $(P=0.1)$.

By comparing the secondary contraction (15 minutes after addition of $\mathrm{KCl}$ solution), there was a significant decrease between the prazosin group and the P. harmala group at a concentration of $2 \mathrm{mg} / \mathrm{mL}(P<0.001)$. However, there was no significant difference in secondary pulling reduction between the $P$. harmala group treated with concentration of $2 \mathrm{mg} / \mathrm{mL}$ and $\mathrm{NaCl}$ group $(P=0.31)$.

In addition, there was a significant difference in the second contraction between the $P$. harmala group treated with concentration of $4 \mathrm{mg} / \mathrm{mL}$ and $\mathrm{NaCl}$ group $(P<0.001)$. Additionally, a significant difference was observed between the prazosin and $P$. harmala groups with a concentration of $4 \mathrm{mg} / \mathrm{mL}(P=0.048)$, which is borderline and there is little difference in the secondary contraction between the two groups.

Comparing the three groups receiving $P$. harmala extract with concentrations of 1.2 and $4 \mathrm{mg} / \mathrm{mL}$, the analysis showed that the response was dose-dependent with increasing concentration. There was no significant difference between $P$. harmala group with concentration of $1 \mathrm{mg} / \mathrm{mL}$ compared with $P$. harmala group with concentration of $2 \mathrm{mg} / \mathrm{mL} \quad(P<0.05)$. A significant decrease was observed between $P$. harmala group with concentration of $1 \mathrm{mg} / \mathrm{mL}$ compared with $P$. harmala group with concentration of $4 \mathrm{mg} / \mathrm{mL}(P<0.001)$. Meanwhile, there was a significant decrease between $P$. harmala group with concentration of $2 \mathrm{mg} / \mathrm{mL}$ compared with $P$. harmala group with concentration of $4 \mathrm{mg} / \mathrm{mL}(P<0.01)$. The highest reduction in the secondary contraction is related to the $P$. harmala group with a concentration of $4 \mathrm{mg} / \mathrm{mL}$, which is very close to the secondary contraction of the prazosin group.

\section{Discussion}

In the present study, the effects of hydroalcoholic extract of Peganum harmala on human ureteric contractions in vitro were investigated.

Peganum harmala extract treatment showed a significant difference at concentration of $4 \mathrm{mg} / \mathrm{mL}$ compared with $\mathrm{NaCl}$ treatment. The difference in mean secondary stretch at $4 \mathrm{mg} / \mathrm{mL}$ concentration was significantly lower than that of prazosin treatment compared with lower concentrations of $P$. harmala ( 1 and $2 \mathrm{mg} / \mathrm{mL}$ ). In fact, the effect of $P$. harmala extract at the concentration of $4 \mathrm{mg} /$ $\mathrm{mL}$ was closer to the level of prazosin effect. Depending on the dose, the alkaloid derivatives of $P$. harmala seeds (harmine and harmaline) reduce the aortic contractions induced by noradrenaline and KCL (11). The aqueous extract of $P$. harmala caused the elimination of the jejunum contractions of rabbits and pigs produced by acetylcholine (12). Furthermore, another study by Nakada et al on smooth muscle of the ureter wall showed that the herbal drug doxazosin can reduce the contraction of the smooth muscle of the ureter wall, which was also dosedependent. Also, the use of doxazosin reduced the effects of epinephrine contraction on these muscles (13).

Sukwan et al reported that the ginseng root extract (Talinum paniculatum) could significantly prevent selfcontraction of the ureter. This extract also significantly inhibited contractions caused by $\mathrm{KCl}$ and Oxytocin (14). The results of this study were consistent with those of our present study.

In the present study, the use of $P$. harmala extracts, especially at a concentration of $4 \mathrm{mg} / \mathrm{mL}$, reduced the effect of KCl-induced contraction. Since the main factor of contraction of smooth muscle is the presence of calcium ions, they can enter the cell through the active calcium channels and cause smooth muscle contraction. The contraction process continues as long as these calcium channels are open. Therefore, the contraction of the ureters caused by potassium chloride can be due to these channels (15-16).

In the study of Aqel et al, the aqueous extract of $P$. harmala seed had an anti-contractile effect on smooth muscles of the intestine, lung, and arteries of rabbits and pigs. The researchers said the aqueous extract of $P$. harmala seed had anti-spastic, anticholinergic, antihistamine, and anti-adrenergic effects. In their study, the researchers reported that the $P$. harmala seed extract may block the calcium ion transfer through voltage-dependent channels and receptor-dependent canals and cause anticonvulsant effects (12).

It has also been reported that the active compounds of $P$. harmala, such as harmine, harmaline, and harmine, showed vasodilatory effects that appear to be related to the ability to increase NO production. In addition, quinazoline alkaloid and vasicinone isolated from $P$. harmala seed showed relaxant and anti-contractile effects on smooth muscle of arteries in mice $(12,17)$. In the present study, the use of $P$. harmala extract on smooth muscle of the ureter had a severe contraction.

In a previous study by Mirzaie et al, hydroalcoholic extract of $P$. harmala at low concentrations increased 
spontaneous contraction of the uterus muscles and decreased the contraction at high concentration of $400 \mu \mathrm{g} /$ mL. Reducing muscle contractility at high concentration in the present study may be associated with an increase in the concentration of inhibitory compounds present in the extract which compensate the stimulatory effects at low concentrations (18).

Ureteral obstruction induces induction of apoptosis in the kidney tissue. It may also lead in the rats to interstitial tuberculosis, glomerulosclerosis, infiltration of inflammatory cells, and inflammation of the interstitial tissue (4); oxidative stress is likely to play a key role in the onset and continuation of post-obstruction inflammation, resulting in renal tubule injury, interstitial fibrosis, necrosis, and apoptosis. Besides, DNA damage increases and the mechanisms for its repair decrease. It has also been shown that after using antioxidants such as bioflavonoids, the damage and oxidative stress as well as the expression of apoptotic genes in the obstructed kidney decrease (4). Different mechanisms for the protective effect of $P$. harmala and other bioactive compounds in different tissues have been proposed (4). On the other hand, the antioxidant effects of $P$. harmala have been proven in previous studies. Therefore, it could be suggested that $P$. harmala may also have a protective role against the side effects of ureteral obstruction as well as other prostate disorders through anti-oxidant effects.

Active compounds of $P$. harmala are mainly composed of alkaloids such as tetrahydroharmine, harmine and harmaline $(4,19)$. In addition, Astulla et al observed that the $P$. harmala alkaloids (including harmaline and harmine) had anti-plasmodium effects and reduced the contractions in the aorta of the mouse (20).

Other alkaloids in $P$. harmala, such as vasicinone, have anti-proliferative properties and can produce cell cytotoxicity in tumor cells in a laboratory environment (21). Of course, it should not be overlooked that the $\beta$-carboline alkaloids contained in the $P$. harmala can cause poisoning at high doses (22); hence the use of this plant should be done in an effective and non-toxic treatment.

\section{Conclusion}

In this study, we found the administration of $P$. harmala extract can be useful in reducing urinary human ureteric contractions while the best effect was achieved at $4 \mathrm{mg} /$ $\mathrm{mL}$ of $P$. harmala extract.

\section{Authors' contribution}

ZK provided study concept and design, acquisition of data, analysis, and interpretation of data. MS prepared study concept, drafting of the manuscript. ZL supervised the final revision of the manuscript for important intellectual content, and conducted administrative, technical, and material supports. AP conducted administrative, technical, and material supports.

\section{Conflicts of interest}

The authors declared no conflict of interest

\section{Ethical considerations}

Ethical issues (including plagiarism, misconduct, data fabrication, falsification, double publication or submission, redundancy) have been completely observed by the authors.

\section{Funding/Support}

Shahrekord University of Medical Sciences supported this research financially (Grant \# 1462, 2016).

\section{References}

1. 1.Canda AE, Turna B, Cinar GM, Nazli O. Physiology and pharmacology of the human ureter: basis for current and future treatments. Urol Int. 2007;78:289-98. doi: $10.1159 / 000100830$

2. Wein AJ, Kavoussi LR, Partin AW, Craig A. Campbell-Walsh Urology. 11th ed. New York: Elsevier; 2015:984-1005.

3. Sakhaee K, Maalouf NM, Sinnott B. Kidney stones 2012: pathogenesis, diagnosis, and management. J Clin Endocrinol Metabol. 2012; 97:1847-60. doi: 10.1210/ jc. 2011-3492

4. 4.Berrougui $\mathrm{H}$, López-Lázaro $\mathrm{M}$, Martin-Cordero $\mathrm{C}$, Mamouchi M, Ettaib A, Herrera MD. Cytotoxic activity of methanolic extract and two alkaloids extracted from seeds of Peganum harmala L. J Nat Med. 2005; 5:41-5.

5. Bruinvels J, Sourkes T. Influence of drugs on the temperature-lowering effect of harmaline. Eur J Pharmacol. 1968; 4:31-9.

6. 6.Nelson D, Herbet A, Petillot Y, Pichat L, Glowinski J, Hamon M. [3H] Harmaline as a specific ligand of MAO A-I, properties of the active site of MAO A from rat and bovine brains. J Neurochem. 1979; 32:1817-27.

7. McCormick S, Tunnicliff G. Inhibitors of synaptosomal $\gamma$-hydroxybutyrate transport. Pharmacol. 1998; 57:124-31.

8. Chen Q, Chao R, Chen H, Hou X, Yan H, Zhou S, et al. Antitumor and neurotoxic effects of novel harmine derivatives and structure-activity relationship analysis. Int J Cancer. 2005; 114:675-82.doi: 10.1002/ijc.20703.

9. Li W. Extraction of alkaloids from Peganum harmala Land study on their antihydatid chemical composition. J Lanzhou Med Coll. 1995; 22:16-8.

10. Aarons DH, Victor Rossi G, Orzechowski RF. Cardiovascular actions of three harmala alkaloids: harmine, harmaline, and harmalol. J Pharm Sci. 1977; 66:1244-8.

11. 11.Bourogaa E, Jarraya RM, Damak M, Elfeki A. Hepatoprotective activity of Peganum harmala against ethanol-induced liver damages in rats. Arch Physiol Biochem. 2015; 121:62.doi: 10.3109/13813455.2015.1016974.

12. Agel M, Hadidi M. Direct relaxant effect of Peganum harmala seed extract on smooth muscles of rabbit and guinea pig. Int J Pharmacol. 2008; 34:176-82.

13. Nakada SY, Coyle TLC, Ankem MK, Moon TD, Jerde TJ. Doxazosin relaxes ureteral smooth muscle and inhibits epinephrine-induced ureteral contractility in vitro. 
Urology. 2007; 70:817-21.

14. Sukwan C, Wray S, Kupittayanant S. The effects of Ginseng Java root extract on uterine contractility in nonpregnant rats. Physiol Reports. 2014;2:e12230. doi: 10.14814/ phy2.12230.

15. Ventura-Martínez R, Rivero-Osorno O, Gómez C, González-Trujano ME. Spasmolytic activity of Rosmarinus officinalis L. involves calcium channels in the guinea pig ileum. J Ethnopharmacol. 2011;137:1528-32.

16. Godfraind T, Miller R, Wibo M. Calcium antagonism and calcium entry blockade. Pharmacol Rev. 1986;38:321-416.

17. Shi C, Chen S, Wang G, Liao J, Chen C. Vasorelaxant effect of harman. Eur J Pharmacol. 2000; 390:319-325.

18. Mirzaie M, Nosratabadi SJ, Derakhshanfar A, Sharifi I. Antileishmanial activity of Peganum harmala extract on the in vitro growth of Leishmania major promastigotes in comparison to a trivalent antimony drug. Veterinarski Arhiv. 2007; 77:365-75.
19. Wang C, Zhang Z, Wang Y, He X. Cytotoxic constituents and mechanism from Peganum harmala. Chem Biodivers. 2016;13(7):961-8. doi: 10.1002/cbdv.201500384.

20. Astulla A, Zaima K, Matsuno Y Hirasawa Y, Ekasari W, Morita H. Alkaloids from the seeds of Peganum harmala showing antiplasmodial and vasorelaxant activity. J Nat Sci. 2008:62:470-72.doi: 10.1007/s11418-008-0259-7

21. Bremner P, Rivera D, Calzado MA, Obon C, Inocencio C, Beckwith C, et al. Assessing medicinal plants from South-Eastern Spain for potential anti-inflammatory effects targeting nuclear factor-Kappa B and other proinflammatory mediators. J Ethnopharmacol. 2009; 124:295-305. doi: 10.1016/j.jep.2009.04.035

22. Lamchouri F, Zemzami M, Jossang A, Abdellatif A, Israili $\mathrm{ZH}$, Lyoussi B. Cytotoxicity of alkaloids isolated from Peganum harmala seeds. Pak J Pharm Sci. 2013; 26:699706.

Copyright (c) 2019 The Author(s); Published by Nickan Research Institute. This is an open-access article distributed under the terms of the Creative Commons Attribution License (http://creativecommons.org/licenses/by/4.0), which permits unrestricted use, distribution, and reproduction in any medium, provided the original work is properly cited. 